\title{
Phosphorus Nutrition in Dairy Animals: A Review
}

\author{
Jaswinder Singh, J.S. Hundal*, A. Sharma, Udeybir Singh, \\ A.P.S. Sethi and Parminder Singh
}

\begin{abstract}
Guru Angad Dev Veterinary and Animal Sciences University, Ludhiana-141004, Punjab, India
\end{abstract}

*Corresponding author

\section{A B S T R A C T}

\begin{tabular}{|l|}
\hline Ke y w or d s \\
$\begin{array}{l}\text { Phosphorus } \\
\text { nutrition, Dairy } \\
\text { animals }\end{array}$ \\
\hline Article Info \\
\hline $\begin{array}{l}\text { Accepted: } \\
\text { 28 March } 2018 \\
\text { Available Online: } \\
\text { 10 April } 2018\end{array}$ \\
\hline
\end{tabular}

Keywords

\section{Introduction}

Phosphorus (P) was discovered by Hennig Brand in 1669 through urine distillation and it's Greek meaning is "bringer of light or light bearer". P occurs abundantly in nature (0.08$0.12 \%$ weight in earth crust) both as in compound and elemental form. The compound forms of $\mathrm{P}$ are available as a) organic compounds and b) as inorganic salts. The inorganic $\mathrm{P}$ occurs as phosphate while organic $P$ occurs in plants as phytic acid, phospholipid, nucleic acid etc (Mcdowell and Sharpley, 2003).

$\mathrm{P}$ is one of the macro mineral found in every cell of the body and is used in several body
Phosphorus (P) has a key role in production and reproduction performance of dairy animals. However, feeding of high levels of dietary $\mathrm{P}$ has no additional benefits to dairy animals but this practice generally leads to more excretion of $\mathrm{P}$, which in turn causes environmental pollution as $\mathrm{P}$ accelerate eutrophication of surface waters. A practicable and cost-effective approach to managing $\mathrm{P}$ level in the diet of dairy animals is required to minimize excretion of $\mathrm{P}$ in manure without impairing animal performance. Therefore, to access the requirement of $\mathrm{P}$ supplementation to dairy animals in Punjab various reports of status in soils, feed and fodders were reviewed and its supply to the dairy animals were accom this study, it can be concluded that the soil and plants of various districts of Punjab are deficit in $\mathrm{P}$ and there is a need of $\mathrm{P}$ supplementation either in the form of mineral mixture (60-100 g/d) or any other P source in the diet of dairy animals.

processes including critical energy pathways (ATP), cell signalling and synthesis of cell membranes, RNA, DNA and bone (Hill et al., 2008). It is hard to think of any physiological function which would not involve directly or indirectly phosphoric acid compound therefore $\mathrm{P}$ is now widely acclaimed as master mineral. Moreover, it is second most abundant mineral in the body after calcium. Approximately 80 $\%$ of the total $\mathrm{P}$ in cattle body is in the bone and teeth as hydroxyapatite and remaining is distributed in soft tissue and body fluid (NRC, 2001). Furthermore, $P$ is third most costly nutrient of all the diet supplements and accounts for more than $50 \%$ of the cost of typical vitamin-mineral mixes used on dairy farm (Chandler, 1996). Therefore, the aim of 
present review is to (1) broaden the knowledge about $\mathrm{P}$, its metabolism and importance in dairy animals (2) comprehensively evaluate the efficacy of $\mathrm{P}$ supplementation on performance and/or health in ruminants by comparing the outcomes of studies with $\mathrm{P}$ supplementation in dairy animals (3) summarise the current status of $P$ content in soils and plants of various regions in Punjab and to access the $\mathrm{P}$ requirement of Punjab dairy animals.

\section{Role of $P$ in ruminants}

\section{$P$ level in blood}

Whole blood contains 350-450 mg/L and most of which present in the cells. The element occurs in variety of forms (inorganic and organic P), mostly organic form is found. The inorganic form of $\mathrm{P}$ ranges from 4 to $8 \mathrm{mg} / \mathrm{dL}$ (about $10 \%$ is bound to serum protein and 50$60 \%$ in ionized form) for dairy cattle with slight higher value for young animals. The intercellular $\mathrm{P}$ concentration in cattle is about $78 \mathrm{mg} / \mathrm{dL}$ and whole blood contains 6-8 time more $\mathrm{P}$ than plasma as higher concentration of $\mathrm{P}$ is present in erythrocytes (NRC, 2001). The organic $\mathrm{P}$ in plasma is mainly a constituent of phospholipids. All body $\mathrm{P}$ is in a dynamic state of turnover with a half life of about 1.4 hour for blood cell and 1.97 hour for brain. Moreover, plasma is not a reliable indicator of $\mathrm{P}$ status because of the quick compensatory reaction on $\mathrm{P}$ repletion (Valk et al., 2000).

\section{$\mathbf{P}$ in saliva}

In ruminants the salivary glands are the major site for endogenous inorganic phosphorus (Pi) secretion into the gastrointestinal tract (GIT). Salivary Pi has 2 major functions: 1) acts as a buffer in the rumen, 2) provides adequate $P$ for rumen microbes (Cohen, 1990). Salivary secretions of $\mathrm{P}$ constitute about $80 \%$ of the endogenous $\mathrm{P}$ recycled to the gastrointestinal tract (the balance is mainly from bile), depending on dry matter intake (DMI), usually combined with $\mathrm{P}$ intake, and the fiber content of the diet (Care, 1994). The daily secretion rate between 5 and $10 \mathrm{~g} \mathrm{Pi}$ in sheep and between 30 and $60 \mathrm{~g} \mathrm{Pi}$ in cows is achieved by both the high salivary flow-rate and the ability of the salivary glands to concentrate $\mathrm{Pi} 3-8$ folds in comparison with plasma Pi (Breves and Schroder, 1991; Karn, 2001).

\section{$P$ in rumen and rumen micobugs}

Rumen microbes have a $\mathrm{P}$ requirement apart from the animal's requirement which must be met for optimum rumen microbial activities to occur (Breves and Schroder, 1991; Powell et al., 2002). Rumen microbes obtain $\mathrm{P}$ from the $P$ released during fermentation of feed in the rumen and from salivary secretions. The concentration of $\mathrm{P}$ in the rumen contents was reported to be $200-600 \mathrm{mg} / \mathrm{L}$ and in this context Durand and Kawashima (1980) suggested the maximum $\mathrm{P}$ requirement for ruminal microbes is satisfied when the diet contains $4 \mathrm{~g} \mathrm{P} / \mathrm{Kg}$ digestible organic matter. This is equivalent to $<0.30 \%$ dietary P. P is mainly of the inorganic variety which originates from the hydrolysis of organic compound present in diets and from salivary secretions. While, rumen microbes concentrate $\mathrm{P}$ mainly in organic form as nucleotides (Komisarczuk, 1985). Rumen microbes appear to be an intermediary source of $\mathrm{P}$ for the host animal. Salivary $\mathrm{P}$ incorporated by the microbes requires further digestive solubilisation in order to be used by the host animal and would be less available than soluble P (Pfeffer, 1995) or even partly unavailable for the animal (Challa and Braithwaite, 1988; Rodehutscord et al., 2000). It was observed that rumen microbes had higher $\mathrm{P}$ requirement than host animal, therefore, care should be taken to meet the microbes $\mathrm{P}$ requirement (Preston and Fander, 1964; Vitti et al., 1988). Recently, Ramirez- 
Prez and Meschy (2005) proposed that $7 \mathrm{~g}$ $\mathrm{P} / \mathrm{kg}$ fermented organic matter was required for normal rumen function. In another study by Durand and Komisarczuk (1988) reported that available $\mathrm{P}$ (from dietary sources and salivary recycling) within the rumen should be at least $5 \mathrm{~g} / \mathrm{kg}$ of organic matter digested to optimize degradation of cell walls. If a feed is low in its $\mathrm{P}$ content then salivary $\mathrm{P}$ secretion also get lowered which ultimately affect the performance of microorganism in the rumen. However, maximum microbial degradative and synthetic activities can be maintained if ruminal inorganic $\mathrm{P}$ levels are at least 75-100 mg/L (Komisarczuk et al., 1987). Moreover, when cattle were fed $0.12 \%$ dietary $\mathrm{P}$, ruminal fluid concentration was over $200 \mathrm{mg}$ $\mathrm{P} / \mathrm{L}$, considerably greater than the 20 to $80 \mathrm{mg}$ of $\mathrm{P} / \mathrm{L}$ needed for maximum cellulose digestion under in vitro conditions (Chicco et al., 1965). This concentration of $\mathrm{P}$ in rumen is achieved usually in cattle by salivary recycling of $\mathrm{P}$ and from diets adequate to meet the animal's requirement.

\section{Sources for $\mathbf{P}$}

Contents of $\mathrm{P}$ in crops and forages are highly variable and depend on soil fertility, plant species, stage of maturity, climate and fertilization (Underwood, 1981). Temperate grasses contain more $\mathrm{P}$ than tropical grasses; and more mature forage has lower $\mathrm{P}$ contents, with the lowest $\mathrm{P}$ contents measured in summer (Minson, 1990; Valk et al., 2000). P content of crop and forage decline markedly with advancing maturity and season affects the concentration of $\mathrm{P}$ more in legumes than in grass, while, it was reported that during hay and silage making loss of $\mathrm{P}$ occur generally (Coates et al., 1990). $\mathrm{P}$ an essential element for plant growth and occurs in the plant in either an inorganic form (orthophosphate and pyrophosphate) or organic form (phospholipids, phosphosugars, adenosine diphosphate, adenosine triphosphate, nucleic acids polymers, and phytate). Very little or low amounts of $\mathrm{P}$ is located in roots and leaves. In seeds predominant form of $\mathrm{P}$ is phytates which occurs as storage form for both phosphates and inositol (Ravinderan et al., 1995). Of the total $\mathrm{P}$ present in the cereal grains, 60-80\% occurs in conjugation form as phytate i.e. the salts of phytic acid (an anion form of phytic acid). O'dell et al., (1976) reported that $90 \%$ of phytate $\mathrm{P}$ in maize is found in the germ portion of the kernel. On the other hand the aleurone layer of wheat and rice seeds is the richest source of phytate $\mathrm{P}$. Phytin contains $28.2 \% \mathrm{P}$ and constitutes between $1-3 \%$ by weight of many cereal and oil seeds (Nelson, 1967: Cheryan, 1980). Tyagi et al., (1998) reported that wheat contains $0.27 \%$ phytate that accounts for $61 \%$ of the total $\mathrm{P}$ present in it. Moreover, Paik (2000) found that proportion of phytate $P$ varies from $11.9 \%$ in tapioca to $83.1 \%$ in wheat bran.

The average concentration of $\mathrm{P}$ in grain is 3.5$4.5 \mathrm{~g} / \mathrm{kg} \mathrm{DM}$ which is 3-4 times higher than straw. Among grains soluble and insoluble phytate comprises $50-70 \%$, phospholipid, phosphoprotein, nucleic acid $20-30 \%$ and mineral phosphate $8-12 \%$. Introduction of $\mathrm{P}$ fertilizer in soil increases its concentration in plants. The level of $\mathrm{P}$ among various feeds and fodders along with other dietary supplemental sources of $\mathrm{P}$ have been presented in Table 1 and 2.

\section{$\mathbf{P}$ metabolism in dairy animals}

$\mathrm{P}$ in feed can either of inorganic origin like orthophosphate, di and tri substituted inorganic phosphate or of organic origin like phytate phospholipid, phosphoprotein etc. In case of dairy animals salivary secretions also act as a major source of $\mathrm{P}$ and its concentration in cattle saliva is $370-720 \mathrm{mg} / \mathrm{L}$ (Clark et al., 1953). Inorganic $\mathrm{P}$ sources which are water soluble are available for absorption 
in ruminant, while the solubility of $\mathrm{P}$ in organic compound depends upon the ability of e animal to convert organic into inorganic form or more acceptable organic form (Underwood and Suttle, 1999). In rumen, micobes secrete phytase enzymes which hydrolysed the phytate $\mathrm{P}$ and released inorganic $\mathrm{P}$. The organic $\mathrm{P}$ which is not hydrolysed in rumen becomes soluble in low $\mathrm{pH}$ of abomasums (Breves and Schroder, 1991; Care, 1994). Under certain circumstances like formaldehyde or heat treatment of seeds, there is decrease in the efficiency of phytase activity as phytate $\mathrm{P}$ become inaccessible to phytase or there is saturation of rumen phytase by large amounts of dietary phytate P (Pfeffer, 1995; Konishi et al., 1999; Park et al., 1999).

Generally, absorption of ingested $\mathrm{P}$ depends upon its solubility at the point of contact with the absorbing membranes (Mcdowell, 1992). It is primarily absorbed in the small intestine mainly in duodenum and jejunum (Reinhardt et al., 1988; Care, 1994), but the relationship between $\mathrm{P}$ intake and $\mathrm{P}$ absorption is still inconclusive whether it is inverse relationship or curvilinear (Morse et al., 1992). Furthermore, only a small amount of $\mathrm{P}$ is absorbed from rumen, omasum and abomasums which still need to be researched thoroughly (Breves and Schroder, 1991).

Absorption of $\mathrm{P}$ occurs via two district mechanisms

Vitamin D dependent active transport system operates mainly when animals are fed low dietary P.

Passive absorption occurs when large amount of absorbable $\mathrm{P}$ is consumed.

The excess of inorganic phosphate formed in the process of the exchange or liberated during resorption of bone tissue is excreted from the body via the kidney. In poultry, rabbit, small lab animals and young ruminants (during first two weeks of their life), $\mathrm{P}$ is eliminated mainly through the kidney i.e through urine. In Pig it is eliminated to equal extent through urine and faeces while in adult ruminant all most all $\mathrm{P}$ excretion occur through faeces (Betteridge et al., 1986). Recently, AlvarezFuentes et al., (2016) reported that on average, lactating dairy cows excreted $58 \%$ of ingested $\mathrm{P}$ in feces and $0.44 \%$ in urine, and secreted $40 \%$ in milk. Whereas, at constant $\mathrm{P}$ intake, cows with higher milk production excreted less $\mathrm{P}$ than cows with lower milk production. Fecal excretion of $\mathrm{P}$ contains three fraction 1) $\mathrm{P}$ of dietary origin unavailable for absorption or not absorbed 2) $\mathrm{P}$ of endogenous origin that inevitably has to be excreted under actual nutritional and physiological conditions 3) $\mathrm{P}$ of endogenous origin which is excreted to maintain homeostasis (NRC, 2001). Therefore, the study of $\mathrm{P}$ and efficiency of its utilization in dairy animals is not simple because of enormous amount of $\mathrm{P}$ is secreted endogenously in the saliva which sometimes surpasses the total amount of endogenous $\mathrm{P}$ excreted in faeces (Kleiber et al., 1951).

\section{Role of $P$ in milk production and reproduction}

$\mathrm{P}$ required for milk production comprises a major fraction of the total $\mathrm{P}$ requirements of a modern dairy cow (NRC, 2001). The $\mathrm{P}$ requirement according to various feed evaluation systems of a $600-\mathrm{kg}$ nonpregnant cow producing $30 \mathrm{~kg}$ of milk/d varies between 59 and 85 g/d (Valk et al., 2000). Recently, Klope et al., (2013) reported that milk P (g/d) is inherently related to milk yield and probably milk yield will be higher at higher intake levels of P. As per NRC (2001), the average milk $\mathrm{P}$ concentration is $0.9 \mathrm{~g}$ of $\mathrm{P} / \mathrm{kg}$ of milk and for lactating dairy cow range of $\mathrm{P}$ is from 0.30 to $0.40 \%$ of the diet DM, whereas, for dry cows about 0.22 to $0.26 \%$ 
dietary $\mathrm{P}$ is sufficient to meet their requirements. Similarly, results of $\mathrm{Wu}$ et al., (2000) indicated that dietary $\mathrm{P}$ at 0.38 to 0.40 $\%$ is sufficient for high producing cows, whereas an apparent digestibility of $\mathrm{P}$ of $40 \%$ or less might be an indicator of excessive intake of $\mathrm{P}$.

$\mathrm{P}$ has been most commonly associated with decreased reproductive performance in dairy cows. Natural deficiencies of $\mathrm{P}$ were reported to cause subnormal fertility, depressed or irregular oestrus and delayed conception in cattle (Morrow, 1969). But, there is no evidence that suggests feeding $\mathrm{P}$ in excess of NRC (2001) requirements improves reproductive performance. Recently, Lopez et al., (2002) reported that feeding $\mathrm{P}$ in excess of NRC (2001) recommendations has no effect on reproductive performance in lactating cows. In this study a total of 267 Holstein cows were randomly assigned at calving to a control diet containing $0.37 \% \mathrm{P}$ (dry basis) or to a treatment diet containing $0.57 \% \mathrm{P}$. Results (Table 3) of this study revealed that feeding of higher $\mathrm{P}$ had no effect on any of the observed reproductive parameters and no effect on milk production or milk composition. But, still higher level of $\mathrm{P}$ are being fed to animals may be because of 1) Lack of scientific literature providing the absolute minimum $\mathrm{P}$ requirement of lactating dairy animals to support moderate to high levels of milk production 2) Aggressive marketing of $\mathrm{P}$ supplements.

\section{P status in Punjab}

\section{Soil and plant status}

Most of the soil in Punjab is deficient in $\mathrm{P}$ (Brar, 1979) and rich in molybdenum (Mo) content (Nayyar et al., 1980). Both these elements $\mathrm{P}$ and Mo interact in antagonistic manner, so fodder raised on such soil produces $\mathrm{P}$ deficiency in plants and therefore in animals
(Dhillon et al., 1972). Moreover, high aluminium ( $\mathrm{Al})$ and iron $(\mathrm{Fe})$ contents of soil also bring out $\mathrm{P}$ deficiency by forming insoluble non-absorbable P-complexes (Mcdowell et al., 1992) and diet containing high $\mathrm{Al}$ reduced $\mathrm{P}$ bioavailability significantly (Crowe et al., 1990). Motsara (2002) reported that in Punjab 29, 49 and 22\% of soil samples are low, medium and high in $\mathrm{P}$ content, respectively. It was also observed that the $\mathrm{P}$ deficiency in green fodder was comparatively higher in the summer season $(21.2 \%)$ than in winter season (13.4\%) (Sikhtajinder, 2012). The available $\mathrm{P}$ content $(\mathrm{Kg} /$ hectare) in soil, straw, green fodder and concentrate ingredients in different zone of Punjab have been illustrated in Table 4 and 5, respectively.

A study conducted by Sikhtajinder (2002) reported that $66.67,55.56,18.18$ and $11.11 \%$ samples of bajra, maize, berseem and oat of Ludhiana, Sangrur and Fatehgarh Sahib district, respectively were deficient in $\mathrm{P}$. Whereas, the level of $\mathrm{P}$ in maize, bajra, berseem fodder was found to be 2500, 1200 and $2800 \mathrm{ppm}$, respectively (Gupta and Ahuja, 1998). However, in Bathinda district the overall mean $\mathrm{P}$ level in fodder was $0.31 \%$ (Sashitola, 2011) which was well above the critical limit i.e., 0.25\% (Mcdowell, 2003). P level in green and dry fodder of Mansa and Ferozepur district of Punjab (Sikhtajinder, 2012) has been provided in Table 6 .

\section{Animal status}

Among all districts of Punjab, high incidences of hypophosphatemia were recorded in cows (71.4\%) as compared to buffaloes $(41 \%)$ of Ferozepur district (Randhawa, 2007; Bhandari et al., 2015). Overall deficiency of $\mathrm{Pi}$ in $\mathrm{CB}$ cows of Ludhiana, Sangrur and Fatehgarh Sahib district was $31.82,31.43$ ad $50.0 \%$, respectively, while, in buffaloes it was found to be $25.00,32.05$ and $41.17 \%$ deficit, respectively. 


\section{Requirement of $\mathbf{P}$}

\begin{tabular}{|l|l|l|l|l|l|}
\hline Ingredients & $\begin{array}{l}\text { Amount } \\
\text { fed(Kg) }\end{array}$ & $\begin{array}{l}\text { DM } \\
(\mathbf{K g})\end{array}$ & $\begin{array}{l}\text { Protein } \\
(\mathbf{K g})\end{array}$ & $\begin{array}{l}\text { TDN } \\
(\mathbf{K g})\end{array}$ & $\begin{array}{l}\text { P } \\
(\mathrm{g})\end{array}$ \\
\hline Maize & 40 & 8 & 0.8 & 4.8 & 16 \\
\hline Wheat straw & 0.55 & 0.5 & 0.01 & 0.2 & 0.04 \\
\hline Concentrate & 4 & 3.5 & 0.7 & 3 & 31.5 \\
\hline Total & & 12 & 1.5 & 8 & 47 \\
\hline Requirement & & 12 & 1.4 & 7.2 & 48 \\
\hline Extra & & - & 0.1 & 0.8 & - \\
\hline
\end{tabular}

Table.1 P Status of dry and green forages on DM basis

\begin{tabular}{|c|c|c|c|c|c|}
\hline Sr. No. & Feed stuff & $\mathbf{P}(\%)$ & Sr. No. & Feed stuff & $\mathbf{P}(\%)$ \\
\hline $\mathbf{1}$ & Maize stover & 0.16 & 2 & Sorghum stover & $\mathbf{0 . 1 2}$ \\
\hline $\mathbf{3}$ & Rice straw & 0.09 & 4 & Wheat straw & $\mathbf{0 . 0 6}$ \\
\hline $\mathbf{5}$ & Urd straw & 0.18 & 6 & Ground nut Straw & $\mathbf{0 . 1 7}$ \\
\hline $\mathbf{7}$ & Gram straw & 0.14 & 8 & Cowpea green & $\mathbf{0 . 2 5}$ \\
\hline $\mathbf{9}$ & Lucerne green & 0.31 & 10 & Guar green & $\mathbf{0 . 2 4}$ \\
\hline $\mathbf{1 1}$ & Oat green & 0.29 & 12 & Bajra green & $\mathbf{0 . 2 9}$ \\
\hline $\mathbf{1 3}$ & Barley grain & 0.37 & 14 & Maize grain & $\mathbf{0 . 3 1}$ \\
\hline $\mathbf{1 5}$ & Wheat bran & 0.91 & 16 & Oat grain & $\mathbf{0 . 3 6}$ \\
\hline $\mathbf{1 7}$ & Bajra grain & 0.34 & 18 & Sorghum grain & $\mathbf{0 . 2 8}$ \\
\hline $\mathbf{1 9}$ & Guar Chuni & 0.58 & 20 & Mustard Cake & $\mathbf{1 . 1 8}$ \\
\hline $\mathbf{2 1}$ & Sesame cake & 1.09 & 22 & Cotton seed cake & $\mathbf{0 . 4 9}$ \\
\hline $\mathbf{2 3}$ & Linseed cake & $\mathbf{0 . 5 2}$ & & & \\
\hline
\end{tabular}

Table.2 Dietary supplements of $\mathrm{P}$

\begin{tabular}{|c|c|c|c|}
\hline Sr. No. & Name & Ca\% & P\% \\
\hline 1 & Dicalcium phosphate & 23 & 18 \\
\hline 2 & Monocalcium phosphate & 16.4 & 21.6 \\
\hline 3 & Steamed bone meal & 31.5 & 14.2 \\
\hline 4 & Tricalcium phosphate & 38 & 19.5 \\
\hline 5 & Sodium tripolyphosphate & -- & 25 \\
\hline 6 & Deflourinated phospahte & 32 & 16.2 \\
\hline 7 & Low fluorine phosphate & 36 & 14 \\
\hline 8 & Soft phosphate & 17.2 & 9.1 \\
\hline 9 & Phosphoric acid & --- & 31.6 \\
\hline 10 & Ammonium phosphate & 0.52 & 20.6 \\
\hline & & Source (Garg et al., 2005) \\
\hline
\end{tabular}


Table.3 Characteristics of estrous behaviour for lactating cows fed diets containing $0.37 \%$ or $0.57 \% \mathrm{P}$

\begin{tabular}{|c|c|c|}
\hline Characteristics & $\mathbf{0 . 3 7} \mathbf{~ P}$ & $\mathbf{0 . 5 7} \% \mathbf{~ P}$ \\
\hline Days to first natural estrous & 68 & 67 \\
\hline Days to first service & 89 & 90 \\
\hline Conception rate at first AI & 39.4 & 42.0 \\
\hline Overall conception rate at 30 d & 34.3 & 38.0 \\
\hline Pregnancies lost (30 to 60 d) & 15.2 & 16.2 \\
\hline Pregnancies lost after 60 d & 6.0 & 5.4 \\
\hline Days open & 112 & 116 \\
\hline Services/conception & 2.9 & 2.6 \\
\hline Anovulatory condition \% & $29.9(40 / 134)$ & $27.1(36 / 133)$ \\
\hline & & (Lopez et al., 2002) \\
\hline
\end{tabular}

Table.4 Status of available P content (Kg/hectare) in soil of Punjab

\begin{tabular}{|c|c|c|}
\hline P Catagories with range & Mean available P & Percent area of state \\
\hline Low (<12) & 5.11 & 36.6 \\
\hline Medium (12-22) & 16.47 & 17.8 \\
\hline High (22-50) & 32.58 & 19.6 \\
\hline Very High (>50) & 108.89 & 26.2 \\
\hline
\end{tabular}

(Sharma et al., 2011)

Table.5 P status in straw, green fodder and concentrate ingredients in different zone of Punjab

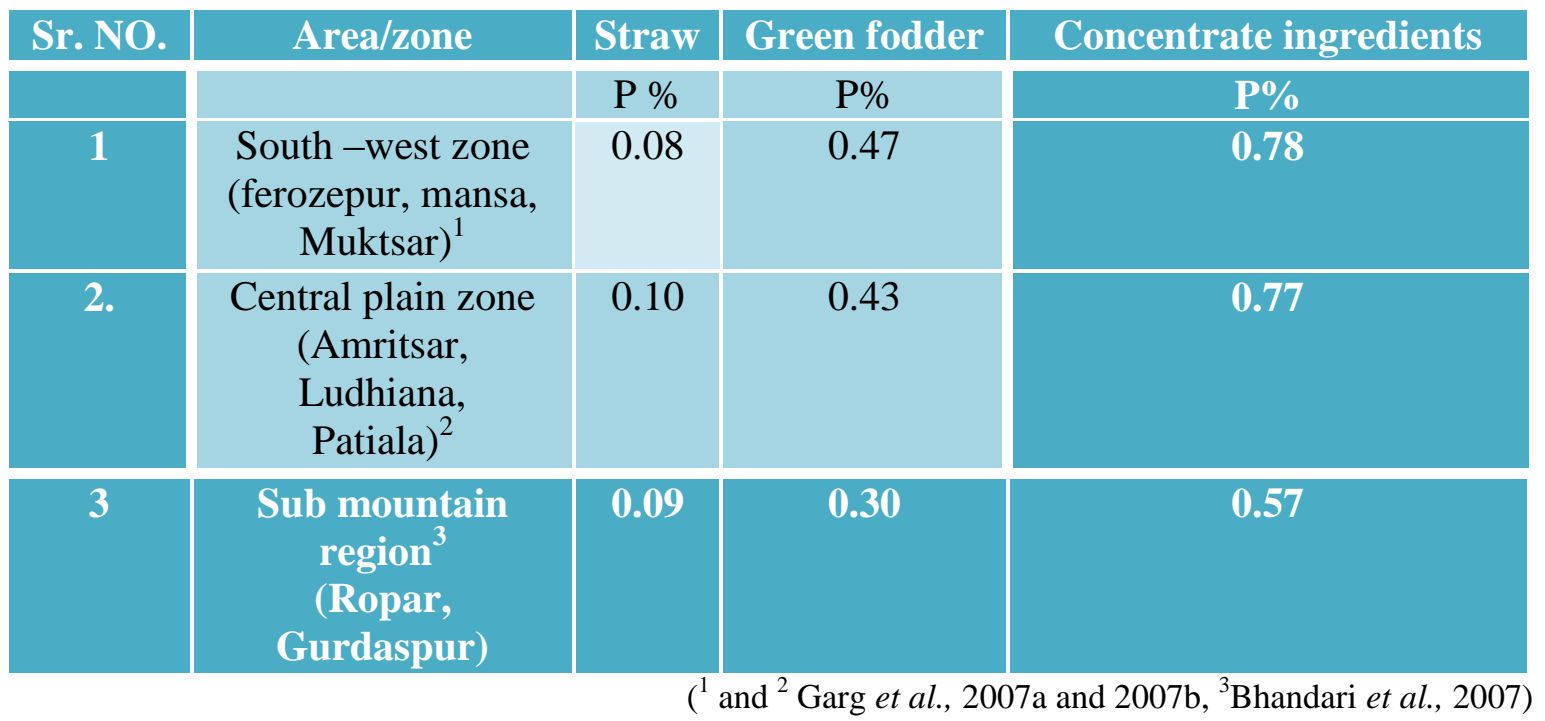


Table.6 Level of P in green and dry fodder of Mansa and Ferozepur district of Punjab

\begin{tabular}{|c|c|c|c|c|c|}
\hline Mineral & $\begin{array}{c}\text { Critical } \\
\text { level }\end{array}$ & \multicolumn{2}{|c|}{$\begin{array}{c}\text { Green fodder overall } \\
\text { deficiency/excess }(\boldsymbol{\%})\end{array}$} & \multicolumn{2}{|c|}{$\begin{array}{c}\text { Dry fodder overall } \\
\text { deficiency/excess (\%) }\end{array}$} \\
\hline & & Mansa & Ferozepur & Mansa & Ferozepur \\
\hline Phosphorus & $0.25 \%$ & 28.3 low & 6.5 low & 100 low & 100 low \\
\hline Molybdenum & $3 p p m$ & 41.5 excess & 29.5 excess & 98.4 excess & 98.3 excess \\
\hline
\end{tabular}

Table.7 P requirements (g/d) for maintenance of cattle and buffaloes

\begin{tabular}{|c|c|c|c|c|c|}
\hline $\begin{array}{c}\text { BW } \\
(\mathbf{K g})\end{array}$ & $\begin{array}{c}\mathrm{P} \\
(\mathrm{g} / \mathrm{d})\end{array}$ & $\begin{array}{c}\mathrm{BW} \\
(\mathbf{K g})\end{array}$ & $\begin{array}{c}\mathrm{P} \\
(\mathrm{g} / \mathrm{d})\end{array}$ & $\begin{array}{c}\mathrm{BW} \\
(\mathrm{Kg})\end{array}$ & $\begin{array}{c}\mathrm{P} \\
(\mathrm{g} / \mathrm{d})\end{array}$ \\
\hline $\mathbf{2 0 0}$ & 4 & 400 & 8 & 600 & 12 \\
\hline $\mathbf{2 5 0}$ & 5 & 450 & 9 & 650 & 13 \\
\hline $\mathbf{3 0 0}$ & 6 & 500 & 10 & 700 & 14 \\
\hline $\mathbf{3 5 0}$ & 7 & 550 & 11 & 750 & 15 \\
\hline $\mathbf{4 0 0}$ & 8 & 600 & 12 & 800 & 16 \\
\hline
\end{tabular}

Table.8 Percentage of farmers supplementing mineral mixture to their animals in various districts of Punjab

\begin{tabular}{|c|c|c|c|c|}
\hline $\begin{array}{l}\text { Sr. } \\
\text { No. }\end{array}$ & Zone of Punjab & District selected & $\begin{array}{l}\text { \% Farmer using MM } \\
\text { for their animals }\end{array}$ & References \\
\hline 1. & $\begin{array}{l}\text { Sub-mountainous } \\
\text { undulating zone }\end{array}$ & $\begin{array}{c}\text { Nawan Sahar } \\
\text { Hoshiarpur }\end{array}$ & 2 & $\begin{array}{c}\text { Hundal et al., } \\
(2007)\end{array}$ \\
\hline 2. & Central Plain zone & $\begin{array}{l}\text { Ludhiana } \\
\text { Kapurthala }\end{array}$ & $\begin{array}{c}25 \\
14.3\end{array}$ & $\begin{array}{c}\text { Kaushal et al., } \\
\text { (2007) }\end{array}$ \\
\hline 3 & Flood prone bait zone & $\begin{array}{l}\text { Tarntaran } \\
\text { Jalandhar }\end{array}$ & $\begin{array}{c}5 \\
28.8\end{array}$ & $\begin{array}{l}\text { Wadhwa et al. } \\
\text { (2007a) }\end{array}$ \\
\hline 4 & Undulating plain zone & $\begin{array}{l}\text { Hoshiarpur } \\
\text { Gurdaspur }\end{array}$ & $\begin{array}{c}25 \\
2\end{array}$ & $\begin{array}{l}\text { Kaur et al., } \\
\quad(2007)\end{array}$ \\
\hline 5 & Western plain & $\begin{array}{l}\text { Ferozepur } \\
\text { Moga }\end{array}$ & $\begin{array}{l}2.5 \\
9.6\end{array}$ & $\begin{array}{l}\text { Bakshi et al., } \\
(2007)\end{array}$ \\
\hline 6 & Western zone & $\begin{array}{l}\text { Bathinda } \\
\text { Mansa }\end{array}$ & $\begin{array}{c}10.6 \\
2.5\end{array}$ & $\begin{array}{l}\text { Wadhwa et al. } \\
\qquad(2007 \mathrm{~b})\end{array}$ \\
\hline
\end{tabular}

The mean plasma $\mathrm{Pi}$ level in cattle and buffaloes of Muktsar and Bathinda district was 5.28 and $5.54 \mathrm{mg} / \mathrm{dL}, 4.70$ and 4.86 $\mathrm{mg} / \mathrm{dL}$, respectively (Sashitola, 2011) which was above the critical level of $4.5 \mathrm{mg} / \mathrm{dL}$ (Mcdowell, 2003). The overall incidence of subclinical hypophosphatemia in CB cows and buffaloes was 35.11 and $23.86 \%$, respectively in both the districts. Whereas, the prevalence of hypophosphatemia in central district of Punjab was 29.8 and $26.7 \%$ in CB cows and buffaloes, respectively (Singh, 1999).

\section{Deficiency symptoms of $\mathbf{P}$}

Of all the minerals deficiencies in cattle, the deficiency of $\mathrm{P}$ is the most common one on a 
global level (Mcdowell et al., 1992). Peg-leg, pica and bone chewing are observed or when soil is known to be uniformly $\mathrm{P}$ deficient. Diagnosis of sub-clinical deficiency associated with reduced cattle production is generally both more difficult and more important. When plasma level is less than $2 \mathrm{mg} / \mathrm{dL}$, then deficiency occur. Symptoms of $P$ deficiency include energy deficiencyreproductive problems, pica/ depraved appetite/allotriophagia, osteophagia, sarcophagia, rupturing of achillus tendon in young bulls and haemoglobinurea.

\section{Requirement of $\mathbf{P}$}

As per ICAR (2013) the P requirements of cattle and buffaloes for maintenance are represented in Table 7. In case of growing young and adult cattle/buffaloes the $\mathrm{P}$ requirements are 9 and $6 \mathrm{~g} / \mathrm{Kg} \mathrm{BW}$ gain. Similarly, for one $\mathrm{Kg}$ milk production there is need of $1.8 \mathrm{~g} \mathrm{P}$ by both lactating cattle and buffaloes.

So, for a cow of $400 \mathrm{Kg} \mathrm{BW}$ having $10 \mathrm{Kg}$ milk yields, the $\mathrm{P}$ requirements can be calculated as follow:

Requirements of $400 \mathrm{~kg}$ cow: DMI $=12 \mathrm{Kg}$; $\mathrm{TDN}=7.2 \mathrm{Kg} ; \mathrm{CP}=1.4 \mathrm{Kg}$; and $\mathrm{P}=0.40 \%$ DM is below:

So, from above example it has been concluded that if farmers are feeding concentrate mixture having mineral mixture 2 $\%$ (Mineral mixture contains $\mathrm{P}=12 \%$ ) to their animals then there is no need of supplementing additional $\mathrm{P}$ source to the dairy animals. Supplementation of $\mathrm{P}$ is also necessary as bioavailability of $\mathrm{P}$ from plant sources has been reported to be low due to phytic acid-P (McDowell, 1992). Moreover, Singh et al., (2005) found deficiency of P and other minerals in dairy animals of Punjab yielding $10 \mathrm{Kg}$ of milk per day and suggested mineral supplementation in different agroclimatic zones of Punjab. The percentage of farmers supplementing mineral mixture to animals in various districts of Punjab is presented in Table 8. Therefore, in Punjab there is a need of supplementation of $\mathrm{P}$ either by supplementing $\mathrm{P}$ sources or mineral mixture $(60-100 \mathrm{~g} / \mathrm{d})$ to fulfil the $\mathrm{P}$ requirement of dairy animals.

Optimizing dairy production with the aim to meet the nutritional requirements of dairy animals precisely and minimize the loss of undesired end products to the environment requires promotion of feeding balance ration in the form of total mixed ration under field conditions. The farmers which prepared their concentrate mixture without addition of mineral mixture have to supplement either mineral mixture to their animals @ of 60-100 $\mathrm{g} /$ day [depending upon $\mathrm{P}$ content of mineral mixture $(9$ or $12 \%)$ ] or any other $\mathrm{P}$ supplements in the diet. Recently, $\mathrm{P}$ has received attention for environmental reasons, such as depletion of finite inorganic $P$ sources (e.g., dicalcium phosphate) and pollution of ponds and streams causing eutrophication. Therefore, optimizing $\mathrm{P}$ intake and understanding the factors affecting $P$ utilization will have environmental and economic benefits.

\section{References}

Alvarez-Fuentes, G., Appuhamy, J.A.D.R.N. and Kebreab, E. 2016. Prediction of phosphorus output in manure and milk by lactating dairy cows. J. Dairy Sci. 99:771-782.

Bakshi, M.P.S., Kaur, K., Wadhwa, M. and Kaur, J. 2007. Nutritional status of animals of western plain zone of Punjab. Abstract In proceeding of International Tropical Animal Nutrition Conference held at NDRI, Karnal, India on 4-7 Oct 2007. Pp. 83. 
Betteridge, K., Andrewes, W.G.K., 1986. Intake and excretion of nitrogen, potassium and phosphorus by grazing steers. J. Agric. Sci. (Camb.) 106, 393404.

Bhandari, B.M., Garg, M.R. and Gupta, S.K. 2007. Assesment of dietary macro and micro mineral status of milch buffaloes in sub-mountain zone of Punjab. Abstract In proceeding of International Tropical Animal Nutrition Conference held at NDRI, Karnal, India on 4-7 Oct 2007. pp 51.

Bhandari, B.M., Garg, M.R. and Sherasia, P.L. 2007. Assessing Minerals Status of Dairy Animals in South-West Zone of Punjab. J. Buffalo Sci. 4: 33-39.

Brar, S.P.S. 1979. Fertility status of the Punjab soils. J Res $\mathrm{Pb}$ Agric.Uni.16:361-90.

Breves, G., Schröder, B. 1991. Comparative aspects of gastrointestinal phosphorus metabolism. Nutr. Rev. 4: 125-140.

Care, A.D. 1994. The absorption of phosphate from the digestive tract of ruminant animals. Br. vet. J. 150:197-205.

Challa, J., Braithwaite, G.D. 1988. Phosphorus and calcium metabolism in growing calves with special emphasis on phosphorus metabolism. 2. Studies of the effect of different levels of phosphorus, infused abomasally, on $\mathrm{P}$ metabolism. J Agric Sci. 110: 583-589.

Chandler, P.T. 1996. Environmental challenges as related to animal agriculture-dairy. Page 7 in Nutrient Management of Food Animals to Enhance and Protect the Environment. E. T. Kornegan, ed. CRC Lewis Publishers, New York, USA.

Cheryan, M. 1980. Phytic acid interactions in food systems. CRC Crit. Rev. Food Sci. Nutr. 13: 297-335.

Chicco, C.F., Ammerman, C.B., Moore, J.E., van Walleghem. P.A., Arrington, L.R. and Shirley, R.L. 1965. Utilization of inorganic ortho-, meta- and pyrophosphates by lambs and by cellulolytic rumen microorganisms in vitro. J. Ani. Sci. 24: 355-363.

Clark, R., 1953. A study of the water-soluble phosphate concentration of the ruminal contents in normal and phosphorus de $\AA$ cient animals. Onderstepoort J. Vet. Res. 26: 137-140.

Coates, D.B., Kerridge, P.C., Miller, C.P. and Winter, W.H. 1990. Phosphorus and beef production in northern Australia. 7. The effect of phosphorus on the composition, yield and quality of legume-based pasture and their relation to animal production. Trop. Grassland. 24:209-220.

Cohen, R.D.H., 1980. Le phosphore dans la nutrition des animaux en paturage extensif: une mise au point. Livest. Prod. Sci. 7: 25-37.

Crowe, N.A., Neathery, M.W., Miller, W., Muse, L.A., Crowe, C.T., Varnadee, J.L. and Blackman, D.M. 1990. Influence of high dietary aluminium on performance and $\mathrm{P}$ bioavailability in dairy calves. J. Dairy Sci. 73: 808-18.

Dhillon, K.S., Singh, J. and Bajwa, R. 1972. Treatment of haemoglobinuria due to Mo induced $\mathrm{P}$ deficiency in buffaloes-a note. Indian J. Anim. Sci. 42(12): 99698.

Garg, M.R., Bhandari, B.M. and Gupta, S.K. 2007a. Assessment of mineral status of dairy animals for developing area specific mineral mixture for central plain zone of Punjab. Abstract In proceeding of International Tropical Animal Nutrition Conference held at NDRI, Karnal, India on 4-7 Oct 2007. pp 55.

Garg, M.R., Bhanderi, B.M. and Sherasia, P.L. 2005. Assessment of adequacy of macro and micromineral content of feedstuffs for dairy animals in semi-arid 
zone of Rajasthan. Animal Nutrition and Feed Technology, 5: 9-20.

Garg, M.R., Gupta, S.K. and Bhandari, B.M. 2007b. Dietary mineral status of milch animals in south-west zone of Punjab. Abstract In proceeding of International Tropical Animal Nutrition Conference held at NDRI, Karnal, India on 4-7 Oct 2007. pp 55.

Graf, E., Empson, K.L. and Eaton, J.W. 1987. Phytic acid. A natural antioxidant. J. Biol. Chem. 262: 1164-1150.

Gupta, B.K. and Ahuja A.K. 1998. Mineral availability in forages crops, progressive farming, PAU, Ludhiana, Nov issue. pp. 18-21.

Hill, S.R., Knowlton, K.F., Kebreab, E., France, J. and Hanigan, M.D. 2008. A Model of Phosphorus Digestion and Metabolism in the Lactating Dairy Cow. J. Dairy Sci. 91:2021-2032.

Hundal, J.S., Kaur, J., Wadhwa, M. and Bakshi, M.P.S. 2007. Nutritional status of animals of submountainous undulating zone of Punjab. Abstract In proceeding of International Tropical Animal Nutrition Conference held at NDRI, Karnal, India on 4-7 Oct 2007. pp 80.

Karn, J.F. 2001. Phosphorus nutrition of grazing cattle: A review. Anim. Feed Sci. Technol. 89:133-153.

Kaur, J.,Wadhwa, M., Hundal, J.S., and Bakshi, M.P.S. 2007. Nutritional status of animals of undulating plain zone of Punjab. Abstract In proceeding of International Tropical Animal Nutrition Conference held at NDRI, Karnal, India on 4-7 Oct 2007.pp 82.

Kaushal, S., Sharma, R.K., Kaur, K., Wadhwa, M. and Bakshi, M.P.S. 2007. Nutritional status of animals of central plain zone of Punjab. Abstract In proceeding of International Tropical Animal Nutrition Conference held at
NDRI, Karnal, India on 4-7 Oct 2007.pp 81.

Kleiber, M., Smith, A.H., Ralston, N.P., Black, A.L. 1951. Radiophosphorus $\left(\mathrm{P}^{32}\right)$ as a tracer for measuring endogenous phosphorus in cow's feces. J. Nutr. 45: 253-264.

Klop, G., Ellis, J., Bannink, A., Kebreab, E., France, J. and Dijkstra, J. 2013. Meta analysis of factors that affect the utilization efficiency of phosphorus in lactating dairy cows. J. Dairy Sci. 96:3936- 3949.

Komisarczuk, S. 1985. Étude de l'influence du phosphore sur l'activité fermentaire, la protéosynthèse et les teneurs en ATP de contenus de rumen dans différents systèmes de culture continus. Thèse, Université de Paris Sud Centre d'Orsay.

Konishi, C., Matsui, T., Park, W., Yano, H. And Yano, F. 1999. Heat treatment of soyabean meal and rapeseed meal suppresses rumen degradation of phytate $\mathrm{P}$ in sheep. Anim. Feed Sci. Technol. 80: 115-122.

Lopez, H., Kanitz, E.D., Moreira, V.R., Wiltbank, M.C. and Satter, L.D. 2002. Effect of dietary $\mathrm{P}$ concentration on reproductive performance of lactating dairy cow. J Dairy Sci. 85(suppl): 364(abstr).

Mcdowell, L.R. 1992. Minerals in animal and human nutrition. Academic press, San Diego, CA, USA.

McDowell, R.W. and Sharpley, A.N. 2003. Phosphorus solubility and release kinetics as a function of soil test $\mathrm{P}$ concentration. Geoderma. 112 (1): 143154.

Minson, D. J. 1990. Forage in Ruminant Nutrition. Academic Press, New York.

Morrow, D.A., Roberts, S. J., McEntee, K. and Gray, H.G. 1966. Postpartum ovarian activity and uterine involution in dairy cattle. J. Amer. Vet. Med. Assoc. 149:1596. 
Morse, D., H.H. Head, C.J. Wilcox, H.H. Van Horn, C.D. Hissem, and B. Harris, Jr. 1992. Effect of concentration of dietary phosphorus on amount and route of excretion. J. Dairy Sci. 75:3039-3049.

Morse, D., Head, H.H., Wilcox, C.J., VanHorn, H.H., Hissem, C.D. and Harris B. 1992. Effects of concentration of dietary phosphorus on amount and route of excretion. J. Dairy. Sci. 75: 3039-3049.

Motsara, M.R. 2002. Fertility status of Indian soils. Fertilizer News 47: 15-22

Nayyar, V.K., Randhawa, N.S. and Pasricha, N.S. 1980. Effect of interaction between $\mathrm{Mo}$ and $\mathrm{Cu}$ on the concentration of these nutrients in barseem and its yield. Indian J. Agri. Sci. 50: 434-40.

Nelson, T.S. 1967. The utilization of phytin phosphorus by poultry-A review. Poultry Sci. 46:862-869.

NRC. 2001. Nutrient requirement of dairy cattle. $7^{\text {th }}$ edn. Natl. Academy press, Washington, DC, USA.

O'Dell, B.L., and de Boland, A.R. 1976. Complexation of phytin with proteins and cations in corn germ and oilseed meals. J. Ag., Food Chem. 24:804-808.

Paik, I.K., Um, J.S., Lee S.J. and Lee, J.G. 2000. Evaluation of the efficacy of crude phytase preparations in broiler chickens. Asian-Aust. J. Anim. Sci. 13:673-680.

Park, W.Y., Matsui, T., Konishi, C., Kim, S.W., Yano, F. and Yano, H. 1999. Formaldehyde treatment suppresses ruminal degradation of phytate in soyabean meal and rapeseed meal. Br. J. Nutr. 81: 467-471.

Pfeffer, E. 1995. Mineral and vitamin metabolism. In: Engelhardt WV, Leonhard-Marek S, Breves G, Giesecke D (Eds), Ruminant physiology: Digestion, metabolism, growth and reproduction, Enke, Stuttgart. Pp. 608609.
Powell, J.M., Jackson-Smith, D.B. and Satter, L.D. 2002. Phosphorus feeding and manure nutrient recycling on Wisconsin dairy farms. Nutr. Cycl. Agroecosyst. 62, 277-286.

Preston, R.L. and Pfander, W.H. 1964. P metabolism in lambs fed varying $\mathrm{P}$ intakes. J Nutr 1964, 83: 369-378.

Randhawa, C.S., Randhawa, S.S. and Kumar, A. 2007. Red cell parameter and plasma mineral status of CB Cows in Punjab. Indian J. Dairy Sci. 59:300-06.

Ravindran, V., Komegay, E.T., Denbow, D.M. and Hulet, R.M. 1995. Response of turkey poults to tiered levels of Natuphos" phytase added to soybean meal-based semi-purified diets containing three levels of nonphytate phosphorus. Poultry Science 74, 18431854.

Reinhardt, T.A, Horst, R.L. and Goff, J.P. 1988. Calcium, phosphorus, and magnesium homeostasis in ruminants. Veterinary Clinics of North America: Food Animal Practice 4, 33 1-350.

Rodehutscord, M., Heuvers, H. and Pfeffer, E. 2000. Effect of organic matter digestibility on obligatory faecal P loss in lactating goats, determined from balance data. Anim. Sci. 70: 561-568.

Sashitola, O. 2011. Surveillance, clinical, haematological and therapeutic studies on mineral imbalance in dairy animals of Bathinda District of Punjab. M.V.Sc. thesis submitted to GADVASU, Ludhiana.

Sharma, B.D., Kumar, R., Manchanda, J.S., Dhaliwal, S.S., Thind, H.S. and Singh, Y. 2011. Geospatial fertility status of Punjab soils. Niche area of excellence, Soil and water management in high intensity cropping regions (ICAR project) PAU, Ludhiana.

Singh, C. 1999. Epidemilogical, Immuno pathological and therapeutic studies in 
dairy animals with refernce to $\mathrm{Cu}$ and $\mathrm{I}$. Ph.D. Thesis, PAU, Ludhiana.

Singh, R., Randhawa, S.S. and Kumar, A. 2005. Macro-mineral status of crossbred cattle of Shivalik Hills in relation to soil and fodder. Indian J. Anim. Sci. 75: 1179-1182.

Thompson, L.U. 1986. Phytic acid: a factor influencing starch digestibility and blood glucose response. In: Phytic Acid: chemistry and applications. E. Graf, editor. Pilatus Press, Minneapolis, p. 173-194.

Tyagi, P.K. and Verma, S.V.S. 1998. Phytate phosphorus content of some common poultry feedstuffs. Ind. J. Poult. Sci. 33:86- 88 .

Underwood, E.J. 1981. The mineral nutrition of livestock. CAB, int. London, England.

Underwood, E.J. and Suttle, N.F. 1999. The mineral nutrition of livestock, $3 \mathrm{rd}$ Edition, CABI Publishing, Wallingford, Oxon, UK.
Valk, H., Metcalf, J.A. and Withers, P.J.A. 2000. Prospects for minimizing phosphorus excretion in ruminants by dietary manipulation. J. Environ. Qual. 29:28-36.

Vitti, D.M.S.S., Silva-Filho, J.C., Abdalla, A.L. 1988. $P$ availability for rumen microorganisms: effect of different sources. J. Nuclear Agric. Biol. 17: $186-187$.

Wadhwa, M., Kataria, P., Hundal, J.S. and Bakshi, M.P.S. 2007. Nutritional status of animals of Flood prone bait zone of Punjab. Abstract In proceeding of International Tropical Animal Nutrition Conference held at NDRI, Karnal, India, on 4-7 Oct 2007. pp 81.

Wu, Z., Satter, L.D. and Sojo R. 2000. Milk production, reproductive performance and faecal excretion of $\mathrm{P}$ by cows fed three amounts of P. J. Dairy Sci. 83:1028-1041.

\section{How to cite this article:}

Jaswinder Singh, J.S. Hundal, A. Sharma, Udeybir Singh, A.P.S. Sethi and Parminder Singh. 2018. Phosphorus Nutrition in Dairy Animals: A Review. Int.J.Curr.Microbiol.App.Sci. 7(04): 3518-3530. doi: https://doi.org/10.20546/ijcmas.2018.704.397 